\title{
One-step laparoscopy for the correction of left abomasal displacement in high-yielding Holstein dairy cows
}

\section{Laparoscopia em um passo para correção do deslocamento de abomaso à esquerda em vacas leiteiras de alta produção}

\author{
João Henrique Perotta ${ }^{1 *}$; Rüdiger Daniel Ollhoff ${ }^{2}$; Júlio Augusto Naylor Lisboa ${ }^{3}$; \\ Peterson Triches Dornbusch ${ }^{1}$; Hugo Richard Dÿck ${ }^{4}$; Pedro Irineu Teider Junior ${ }^{4}$; \\ Nilton Vieira ${ }^{5}$ Ivan Roque de Barros Filho ${ }^{1}$
}

\begin{abstract}
Surgical procedures for the correction of abomasal displacement are one of the most frequently performed in dairy cows, and many surgical techniques have been described since the first cases of this disease were reported in the 1950s. Although no report to date has described the use of one-step laparoscopy in Brazil, the technique has several advantages over the traditional techniques, e.g., better abdominal visualization and minor trauma resulting from the minimally invasive technique. Accordingly, one-step laparoscopy, as described by Christiansen and Barisani, was performed to treat left abomasal displacement in 21 high-yielding dairy cows from two dairy regions of Paraná State. The technique was performed without complications in 12/21 (57.14\%) cows. Ruminal (four animals), abomasal (two animals), both ruminal and abomasal (one animal), and splenic (one animal) perforations occurred during surgery but without any postoperative complication. One cow developed pyloric obstruction caused by the toggle bar suture, but early removal restored abomasal flux. Three animals died of different causes. One cow showed recurrence of displacement 1 month after surgery. A third access was necessary in cows that weighed more than $700 \mathrm{~kg}$. One-step laparoscopy is an efficient, fast, and safe technique for the correction of left abomasal displacement.
\end{abstract}

Key words: Dairy cattle. Laparoscopy. Left abomasal displacement.

\section{Resumo}

Os procedimentos cirúrgicos para correção do deslocamento de abomaso estão entre os mais realizados em vacas leiteiras, existindo um grande número de técnicas cirúrgicas desde os primeiros casos da doença, diagnosticado nos anos 1950. Embora não exista informações do uso da técnica de abomasopexia por laparoscopia em um passo no Brasil, esta técnica apresenta várias vantagens em relação a abordagem tradicional, como por exemplo melhor visualização da cavidade abdominal e menor trauma em decorrência da técnica minimamente invasiva. Desta maneira, a técnica de abomasopexia por laparoscopia em um passo segundo Barisani e Christiansen foi utilizada para o tratamento do deslocamento de abomaso à esquerda em 21 vacas leiteiras de alta produção, pertencentes a duas bacias leiteiras do Paraná. A técnica foi realizada sem complicações em 12/21 (57,14\%) das vacas. Ocorreram perfuração ruminal, (quatro animais), do abomaso (dois animais), de ambos rúmen e abomaso (um

\footnotetext{
${ }^{1}$ Profs., Universidade Federal do Paraná, UFPR, Curitiba, PR, Brasil. E-mail: perotta@ufpr.br; petriches@gmail.com; ivanbarf@ ufpr.br

2 Prof., Pontifícia Universidade Católica do Paraná, PUC-PR, Curitiba, PR, Brasil. E-mail: ollhoff@gmail.com

${ }^{3}$ Prof., Universidade Estadual de Londrina, UEL, Londrina, PR, Brasil. E-mail: janlisboa@uel.br

4 Discentes, Universidade Federal do Paraná, UFPR, Curitiba, PR, Brasil. E-mail: hugodyck@gmail.com; p_teider@yahoo.com.br

${ }^{5}$ Médico Veterinário, Arapoti, PR, Brasil. E-mail: nilvie@brturbo.com.br

* Author for correspondence
} 
animal) e do baço (um animal) durante o procedimento cirúrgico, porém sem complicações no pósoperatório. Um animal apresentou obstrução de piloro provocada pelo fio toggle, entretanto a remoção precoce reestabeleceu o fluxo abomasal. Três animais vieram a óbito por diferentes causas. Um animal apresentou recidiva do deslocamento um mês após a operação. Um terceiro acesso foi utilizado em vacas pesando mais de $700 \mathrm{Kg}$. A técnica de laparoscopia em um passo mostrou-se eficiente, rápida e segura para a correção do deslocamento de abomaso à esquerda.

Palavras-chave: Vacas leiteiras. Laparoscopia. Deslocamento de abomaso à esquerda.

\section{Introduction}

Abomasal displacement has been defined as the abnormal movement of the abomasum into the abdominal cavity. It is mostly referred to as left abomasal displacement (LAD) when the abomasum is displaced in a left caudodorsal direction between the rumen and abdominal wall (DIRKSEN, 2006; NIEHAUS, 2008). Studies have shown that LAD is 8 to 9 times more likely to occur than right abomasal displacement (SHAVER, 1997).

The pathogenesis of abomasal displacement has not been fully established, and several factors have been associated with disease development (GEISHAUSER, 1995). Although increased ruminal and abomasal production of volatile fatty acids (SVENDSEN; KRISTENSEN, 1970), negative energy balance (SHAVER, 1997), hypocalcemia (CURTIS et al., 1983), ketosis (ROHRBACH et al., 1999), metabolic alkalosis (POULSEN; JONES, 1974), prostaglandins, and endotoxins (VLAMINCK et al., 1985) have been suggested to play a role in disease pathogenesis, no etiologic agent has been experimentally established to contribute to pathogenesis (BARROS FILHO, 2002; ITOH et al., 2011).

Treatment of LAD has focused on surgical repositioning of the abomasum via several techniques with specific advantages and disadvantages associated with the correction of the acid-base and electrolyte imbalances (BARROS FILHO, 2008). Surgical techniques include right paralumbar omentopexy or the Hannover approach (DIRKSEN, 1961, 1967), left paralumbar omentopexy or the Utrecht approach (LAGERWEIJ; NUMANS, 1962, 1968), ventral paramedian omentopexy
(STRAITON; MCINTEE, 1959), percutaneous abomasal fixation (HULL, 1972), percutaneous fixation with toggle bar suture (GRYMER; STERNER, 1982), two-step laparoscopic abomasopexy (JANOWITZ, 1998), and, more recently, one-step laparoscopic abomasopexy (BARISANI, 2004; CHRISTIANSEN, 2004).

One-step laparoscopic abomasopexy has been considered an advancement of the twostep laparoscopic technique, and is characterized by the ventral (and cranial to navel) fixation of a toggle suture by using a "spieker". Although this technique has been described as being faster, less traumatic, less stressful, and more comfortable (no dorsal recumbence) than the other techniques are (BARISANI, 2004; VAN LEEUWEN et al., 2009), no study to date has described its use in Brazil. Therefore, the present study was conducted to describe the outcomes and complications of 21 dairy cows with LAD treated using one-step laparoscopic abomasopexy.

\section{Material and Methods}

This study was performed on 21 HolsteinFriesian dairy cows with LAD. All cows were from high-yielding dairy farms (higher than $8500 \mathrm{~kg}$ of milk/cow/305 days) of Arapoti-PR (nine farms; 19 animals) and Fazenda Rio Grande-PR (one farm; two animals).

The diagnosis of LAD was established through clinical examination, drop in milk yield, presence of scant and diarrheic faeces, dehydration (skin turgor and eye position in the orbit), and tympanic and metallic ping on auscultation-percussion in the left paralumbar fossa. 
The short-term efficacy (during 1 month) of onestep laparoscopic abomasopexy was evaluated. The surgeries were performed between April 2014 and April 2015 by one surgeon (JHP) with assistance from three others surgeons (RDH, HRD, and IRBF).

One-step laparoscopic abomasopexy was performed according the technique reported by Christiansen (2004) and Barisani (2004). The cows were restrained in yokes and the skin $15 \mathrm{~cm}$ ventral to the transverse process and $5 \mathrm{~cm}$ caudal to the $13^{\text {th }}$ rib was clipped; the cows were then anesthetized using $10 \mathrm{~mL}$ of $2 \%$ lidocaine without a vasoconstrictor. Following skin incision, a trocar (9-mm external diameter, 8-mm internal diameter, and 11.5-cm length) was introduced dorsocaudally, perforating the abdominal muscles and peritoneal membrane (Figure 1). The laparoscope $\left(0^{\circ}, 40\right.$ $\mathrm{cm}$ length, and 7-mm diameter) was introduced through this port and an air pump (4 L/min, 0.2 bar, and $230 \mathrm{~V}$ ) was connected. The work port (12-mm diameter and 12-cm length) was introduced under laparoscopic guidance over the $11^{\text {th }}$ intercostal space after clipping and anesthesia. The abomasum was localized (Figure 2), and the dorsal region (next to the greater omentum attachment in the greater abomasal curvature) was perforated (Figure 3) using a cannula. The toggle bar suture was introduced into the abomasum by using a rod (3$\mathrm{mm}$ diameter and $36.5-\mathrm{cm}$ length), and the viscera was then deflated. The thread was tied to the spieker (1-m length and 11-mm diameter), which was inserted between the rumen and the left body wall up to the right ventral paramedian region. The toggle bar suture was exteriorized after a knock in the high extremity of the spieker localized in the left body wall (Figure 4B), and was tied in ventral abdomen using a gauze roll.

Figure 1. Introduction of a trocar in a $45^{\circ}$ angle to avoid abomasal/ruminal perforation.

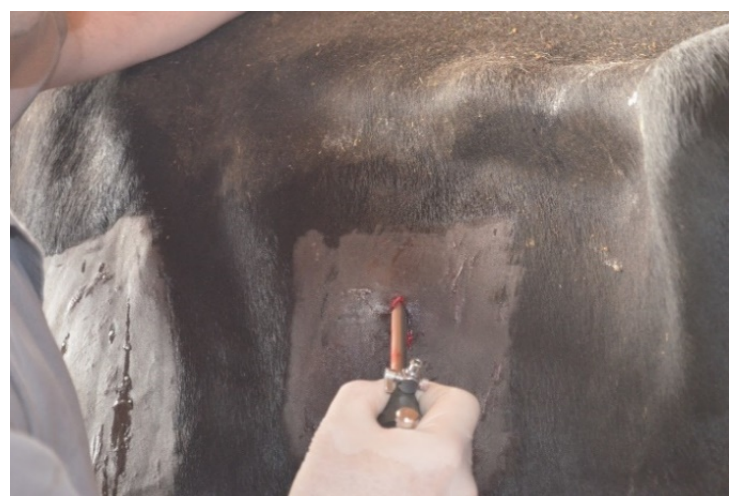

Figure 2. Laparoscopic inspection and confirmation of abomasal displacement. A, abomasum, R, rumen, S, spleen.

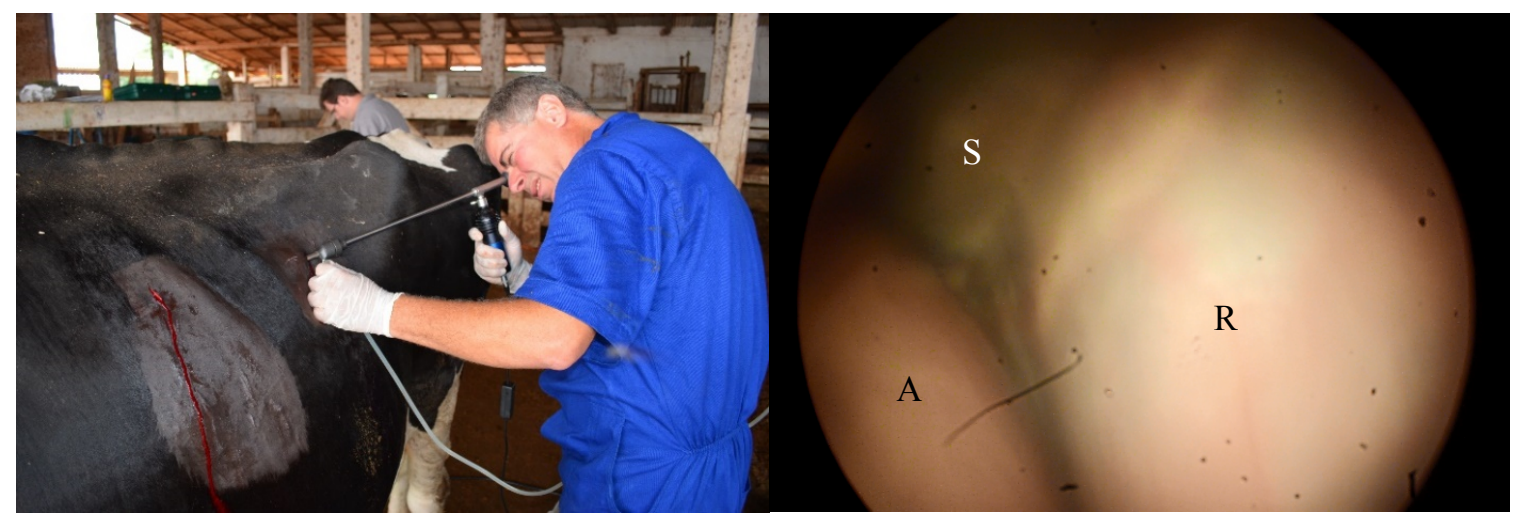


Figure 3. Abomasal deflation under laparoscopic control. The trocar (arrow), which is used to introduce the toggle bar suture inside abomasum is seen via laparoscopy. A, abomasum partially deflated, S, spleen.

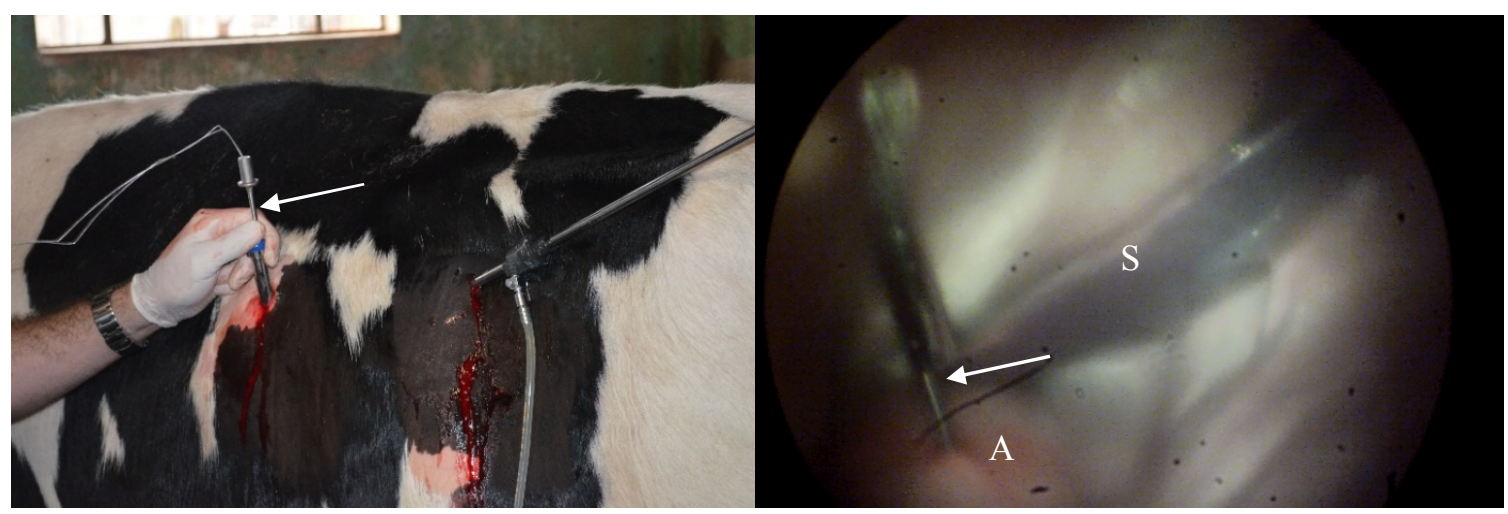

Figure 4. Exteriorization of toggle suture. Figure A shows fixation of nylon thread in the spieker as described by Barisani. Figure B shows exteriorization of toggle suture by Christiansen approach.

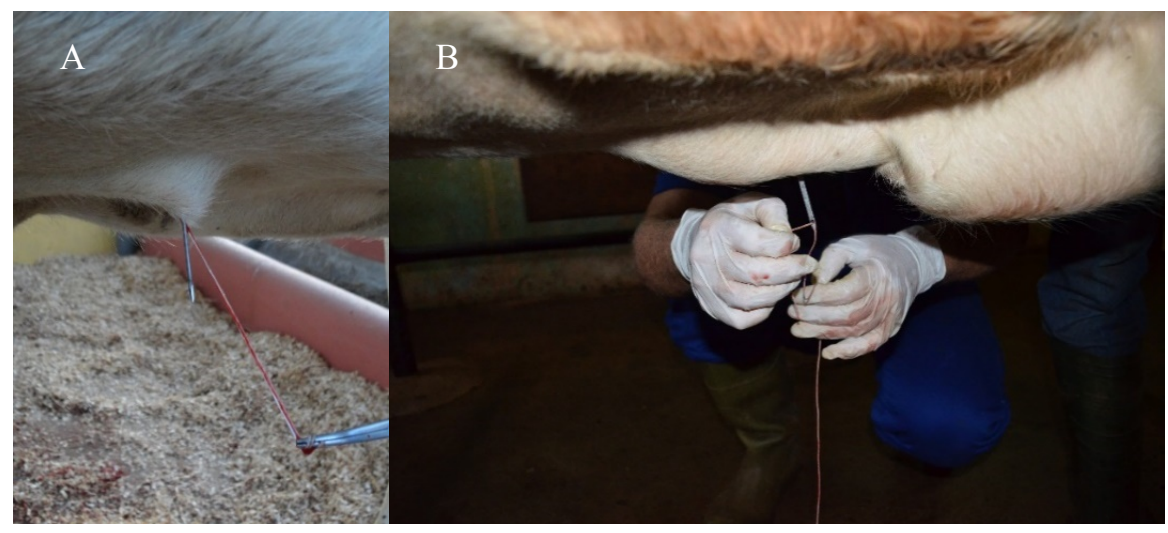

Christiansen (2004) described a modified technique. The procedure was performed conventionally until the introduction of the toggle bar suture into the abomasum. At this point, the spieker was introduced into the abdomen without the toggle suture. The ventral abdomen was perforated, and a nylon thread was tied to the ventral extremity of the spieker (Figure 4A), which was then removed out of the abdomen. At this point, one end of the nylon thread was in the ventral paramedian region and the other in the left body wall. The toggle suture was tied to the nylon thread (Figure 5A), and the ventral extremity was pulled (Figure 5B), exteriorizing the toggle bar suture, which was then tied.
This technique was further modified for cows weighing more than $700 \mathrm{~kg}$, because the spieker could not reach the right paramedian side in such heavier cows. A third access over the $10^{\text {th }}$ or $11^{\text {th }}$ intercostal space and $15 \mathrm{~cm}$ ventral to the second access was used to introduce the work port and spieker. To move the toggle bar suture ventrally, the thread had to be recovered first (Figure 4B) through the third port by using a hook or a clamp used in the technique described by Janowitz (1998). This step was necessary because the thread was in the second port (Figure 6). 
Figure 5. A, toggle bar suture fixation (arrow) at nylon thread (arrow head). B, toggle suture is exteriorized when nylon thread is pulled at right paramedian region.

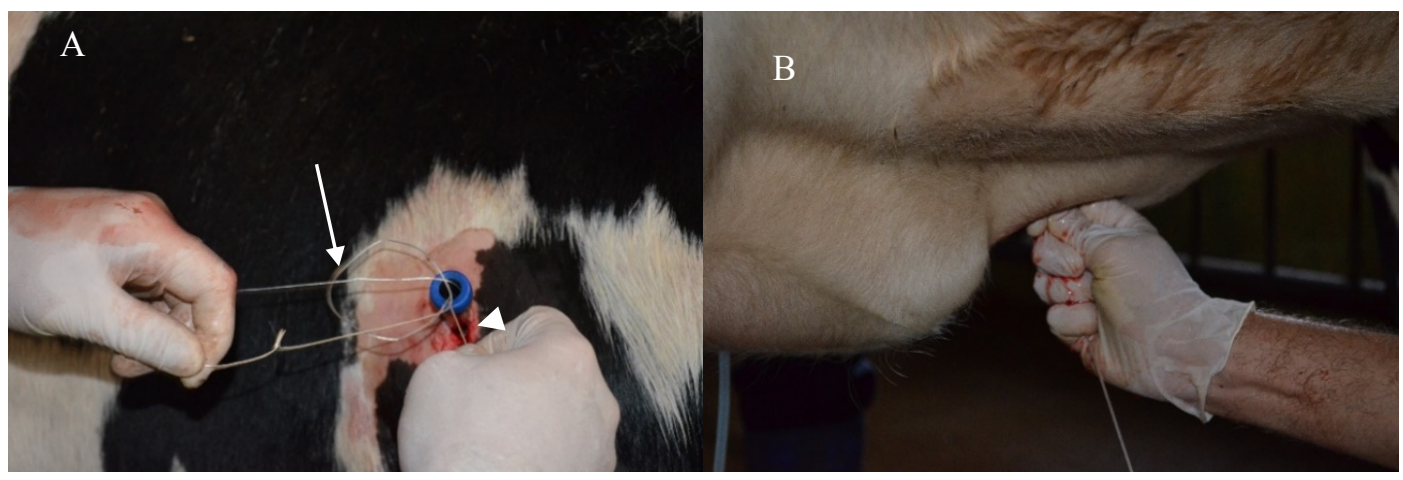

Figure 6. toggle bar suture recovery in a cow which third access was used. This handling should be performed under laparoscopic control. Note the presence of toggle suture in the hands of surgeon. (arrow).

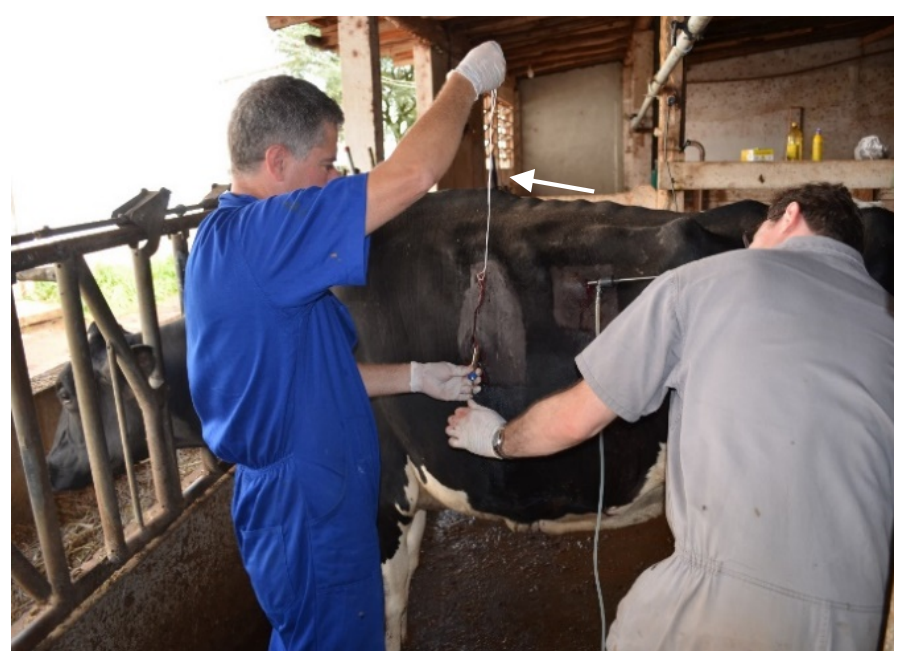

Following surgery, the cows received benzathine benzylpenicillin intramuscularly for 3 consecutive days $(20000 \mathrm{IU} / \mathrm{kg} / 24 \mathrm{~h})$. Surgical wounds were cleaned with povidone iodine and protected against flies. The toggle bar suture was removed 7 days after surgery.

\section{Results}

Data regarding the animals and techniques used in this work, as well as complications, have been described in Table 1. Three animals underwent surgery according to the technique described by Barisani (2004). However, some complications were encountered during that procedure, and hence, the method described by Christiansen (2004) was used. The overall mean duration of surgery was (without the animal's preparation time) $35.04 \pm$ $11.40 \mathrm{~min}$ (range, 20 to $60 \mathrm{~min}$ ).

Three animals died 48, 72, and $120 \mathrm{~h}$ after surgery. One animal had fetid gas and green-colored content inside the uterus at necropsy. Another animal had not shown satisfactory improvement following surgery, and necropsy was not performed to discover the cause of death. One animal had dark, fetid, diarrheic feces; pale mucous membrane; and a packed cell volume of $15 \% 48 \mathrm{~h}$ after surgery. Supportive treatment (fluid-therapy and blood transfusion) was not effective, and the cow died. At 
necropsy, the abomasum was found to have been ruptured at the point of toggle fixation. The cause of abomasal rupture and bleeding was suspected to be a fall, because the owner had reported previous episodes of falling and slips for this animal.

Cow 04 did not recover after surgery, and a blood-gas analysis revealed a diagnosis of metabolic alkalosis with excess of bicarbonate $(48 \mathrm{mmol} / \mathrm{L} 72 \mathrm{~h}$ after surgery), possibly due to a pylorus obstruction.
The toggle suture was cut off, and the cow's clinical condition improved thereafter.

During laparoscopic port introduction, ruminal (four cases), abomasal (two cases), and ruminal plus abomasal (one case) perforations occurred. Splenic perforation also occurred in one animal during trocar introduction into the abomasum, causing a small hemorrhage. Regardless of these accidents, no complications were observed following surgery.

Table 1. Weight, complications and chosen method employed to treat 21 cows with left abomasal displacement by one-step laparoscopic abomasopexy.

\begin{tabular}{|c|c|c|c|}
\hline Animal & $\begin{array}{l}\text { Weight } \\
\text { (Kg) }\end{array}$ & Complications & Observation \\
\hline 1 & 702 & Ruminal perforation & Third access required, subcutaneous emphysema \\
\hline 2 & 750 & Ruminal perforation & - \\
\hline 3 & 518 & Ruminal and abomasal perforation & - \\
\hline 4 & 702 & Ruminal perforation & $\begin{array}{c}\text { Third access required, pylorus obstruction, toggle } \\
\text { bar suture removed } 72 \mathrm{~h} \text { following surgery; } \\
\text { subcutaneous emphysema }\end{array}$ \\
\hline 5 & 795 & Abomasal perforation & $\begin{array}{l}\text { Third access required, abomasum fixed in left } \\
\text { paramedian region; subcutaneous emphysema }\end{array}$ \\
\hline 6 & 563 & abomasal perforation & $\begin{array}{l}\text { Third access required, death due abomasal } \\
\text { perforation } 120 \text { hours after surgery }\end{array}$ \\
\hline 7 & 716 & Splenic perforation & Third access required \\
\hline 8 & 767 & $\begin{array}{l}\text { difficulty in leading the spieker } \\
\text { ventrally }\end{array}$ & $\begin{array}{l}\text { Third access required. Relapsed one month } \\
\text { following surgery }\end{array}$ \\
\hline 9 & 483 & $\begin{array}{l}\text { Toggle thread cut off by trocar tip } \\
\text { (released internally in abdomen) }\end{array}$ & Method of Barisani \\
\hline 10 & 735 & $\begin{array}{l}\text { Toggle suture remained in } \\
\text { subcutaneous tissue }\end{array}$ & Method of Barisani; death $72 \mathrm{~h}$ after surgery \\
\hline 11 & 518 & - & - \\
\hline 12 & 577 & - & - \\
\hline 13 & 681 & - & - \\
\hline 14 & 492 & - & - \\
\hline 15 & 800 & - & Third access required \\
\hline 16 & 767 & - & Third access required \\
\hline 17 & 742 & - & Third access \\
\hline 18 & 490 & - & Subcutaneous emphysema \\
\hline 19 & 577 & - & - \\
\hline 20 & 850 & - & Third access required, relapsed $48 \mathrm{~h}$ after surgery \\
\hline 21 & 762 & - & Method of Barisani \\
\hline
\end{tabular}


The technique described by Barisani (2004) was successfully performed in one animal. In cow 09 , only one thread of the toggle bar suture was exteriorized during right paramedian perforation. Even with one suture inside and another outside, the abomasum could be fixed in place. This animal has not shown any complications or LAD recurrence during 1 month of monitoring. In cow 10, the toggle bar suture knot was tangled subcutaneously, and the skin was cut to exteriorize the suture.

Cow 08 showed a drop in milk yield 1 month after surgery, and an examination revealed LAD recurrence. The animal was subjected to right-side laparotomy, which revealed an adhesion between the abomasum, rumen, and left body wall, as well as detachment of the parietal peritoneum. Considering these complications, the animal was slaughtered. Subcutaneous emphysema was observed in four animals on the dorsal surface of the transverse process of lumbar vertebrae in one animal and around the surgical wound in three.

\section{Discussion}

One-step laparoscopic abomasopexy has been effectively used to treat LAD under field conditions, despite the use of fragile devices. The procedure can be promptly accomplished by two surgeons. By adopting basic antiseptic care techniques, the cows can be operated on without serious complications such as peritonitis. Laparoscopy also allows visualization of the dorsal rumen, displaced abomasum, spleen, and diaphragm. Moreover, all animals well tolerated the procedure performed in a standing position, using only a yoke restraint and local anesthesia.

This technique has been described as being simpler than two-step laparoscopic abomasopexy, because it can be performed with the animal in the standing position, thereby avoiding aspiration pneumonia, injuries, and uterine and mesenteric torsion (NEWMAN et al., 2008; VAN LEEUWEN et al., 2009). However, the technique also has some disadvantages including the inability to visualize the cranial abdomen and recognize adhesions between the rumen, reticulum, omentum, or right paramedian wall; risk of including the greater omentum in the suture; and abomasal perforation during spieker introduction towards the right paramedian region (NEWMAN et al., 2008).

The average surgical time in this study was higher than that reported in the literature (35 $\mathrm{min}$ vs. $20 \mathrm{~min}$ ) (BARISANI, 2004; CHRISTIANSEN, 2004). This difference could probably be attributed to the number of cases in which a third access port was used in this study (47\%), which increased the surgical time. The lower experience of the surgeons in this study compared to those in the literature (21 vs. 200 animals operated) could also have contributed to the increased surgical time.

Surgicalaccidentsduring laparoscopicprocedures have been described previously (BARISANI, 2004; CHRISTIANSEN, 2004; GNEMMI, 2006; VAN LEEUWEN et al., 2009). Abomasal perforation can occur when the viscus is highly distended and occupies the cranial portion of the left paralumbar region through which the laparoscopic and work ports were introduced. To avoid this accident, the abomasum was deflated using a Veress needle prior to port introduction. Ruminal perforation can occur when the viscus was distended or next to the left body wall (abomasum partially distended). To avoid this accident, the angle of introduction of the port trocar was set at $45^{\circ}$ dorsocaudally (Figure 1) and presurgical left paralumbar fossa massage was given to all the animals.

Gnemmi (2006) have described complications not observed in this study. These include the persistence of the toggle bar suture inside the trocar without moving into the abomasum, the toggle bar suture falling into the abdominal cavity during trocar withdrawal or during trocar rod insertion, release of gas from the abomasum through the trocar during toggle bar insertion, and ventral sliding of the abomasum. Nevertheless, by accurately performing 
the described movements under laparoscopic guidance, the two surgeons could ensure successful completion of each surgical step.

Abomasal fistula (CHRISTIANSEN, 2004; GNEMMI, 2006), circumscribed peritonitis, and paramedian myositis at the toggle bar suture fixation site (BARISANI, 2004) were not observed in this study. The adoption of aseptic surgical methods and administration of antibiotics to all animals after surgery could have contributed to the absence of peritonitis, which was observed in the study by Barisani (2004) who did not adopt these practices in all animals.

Using the method described by Barisani (2004) resulted in complications in two animals, as has also been described by Van Leeuwen et al. (2009). These complications included lodging of the toggle bar suture in the subcutaneous tissue and shearing off of threads. The knot joining the threads can produce friction against the big needle, thereby preventing the thread from sliding off the trocar. These complications are known to increase surgical time and hamper correct abomasal fixation.

Clinical and laboratory evaluations performed within $48 \mathrm{~h}$ of surgery have been decisive in diagnosing pyloric obstruction caused by the toggle bar suture (KELTON; FUBINI, 1989). The lack of appetite and defecation (VAN LEEUWEN et al., 2009) associated with metabolic alkalosis (48 $\mathrm{mmol} / \mathrm{L}$ ) is also an indication of this surgical complication. However, premature removal of the toggle bar suture can help correct this problem, as reported by Kelton and Fubini (1989) and Van Leeuwen et al. (2009).

Intraabdominal air introduction could induce subcutaneous emphysema (VAN LEEUWEN et al., 2009). In this study, the use of an air pump could not distend the abdominal cavity sufficiently, and hence, its use was discontinued. Apart from the aesthetic appearance of the surgical region, reported by the owners, no other complications were reported until resolution. Spieker introduction induced discomfort and pain in some cows, probably caused by friction of the needle tip against the peritoneum, because of the straight configuration of the needle.

The decision to use a third access port to correct LAD in cows weighing over $700 \mathrm{~kg}$ was based on previous experience of difficulty reaching the right ventral paramedian abdomen to fix the abomasum in large cows; nevertheless, left-side fixation does not result in further complications (VAN LEEUWEN et al., 2009). The absence of information in the literature about this modification to the original technique prompted us, on the basis of the experience acquired, to specify this weight $(700 \mathrm{~kg})$ as a criterion for deciding which technique to use for surgery.

The greatest risk of using a third access port was ruminal perforation during work port introduction, because at this time, the abomasum has returned to its anatomical position, allowing the rumen to touch the left body wall. The introduction of the work port should be done under laparoscopic guidance to prevent ruminal perforation. In this study, the abomasum could not be fixed on the right paramedian region by using the third access port only in one animal.

Minimally invasive surgical techniques have not ensured permanent abomasal fixation, and the adhesions formed initially have disappeared in about $60 \%$ of the cases until the subsequent lactation period (AL-BAYATI, 2011). Christiansen (2004) reported a recurrence rate of $0.019 \%$ (three of 152 animals operated), but did not describe how long the observation time was. In this study, two animals had LAD recurrence during the study period - one because of a technical error (fixation on the left paramedian side) and the other because of a lack of adhesion. However, recurrence was not observed in any of the treated cows during the subsequent lactation period. 


\section{Conclusion}

One-step laparoscopic abomasopexy has proved efficient in correcting LAD under field conditions. Moreover, although complications previously reported in the literature were observed in this study, these did not affect surgical efficiency. The study findings suggest that the possibility of treating LAD via a faster, safer, and less traumatic procedure justifies the use of expensive laparoscopic equipment.

\section{References}

AL-BAYATI, A. Development of abdominal adhesions after laparoscopic abomasopexy. 2011. (PhD Thesis) College of Veterinary Medicine, Justus-Liebig University Giessen, Giessen.

BARISANI, C. Evoluzione della tecnica di Janowitz per la risoluzione della dislocazione abomasale sinistra secondo Barisani. Summa, Milano, n. 5, p. 35-39, 2004.

BARROS FILHO, I. R. Métodos de correção do deslocamento do abomaso: existem novidades? In. CONGRESSO BRASILEIRO DE CIRURGIA E ANESTESIOLOGIA VETERINÁRIA, 8., 2008, Recife. Anais... Recife: Congresso Brasileiro de Medicina Veterinária, 2008. p. 45-51.

Perioperative Veränderungen im SäureBasen und Elektrolythaushalt von abomasopexierten oder omentopexierten Kühen mit linksseitiger Labmagenverlagerung. 2002. Dissertation (Doctor MedicineVeterinary) - Tierärztliche Hochschule Hannover, Hannover.

CHRISTIANSEN, K. Laparoskopisch kontrollierte Operation des nach links verlagerten Labmagens (Janowitz-Operation) ohne Ablegen des Patienten. Tierärztliche Praxis Ausgabe G Grosstierel Nutztiere, Stuttgart, v. 32, n. 5, p. 118-121, 2004.

CURTIS, C. R.; ERB, H. N.; SNIFFEN, C. J.; SMITH, R. D.; POWERS, P. A.; SMITH, M. C.; WHITE, M. E.; HILMAN, R. B.; PEARSON, E. J. Association of parturient hypocalcemia with eight periparturient disorders in Holstein cows. Journal of the American Veterinary Medical Association, Schaumburg, v. 183, n. 5, p. 559-561, 1983.
DIRKSEN, G. Die Erweiterung, verlagerung und drehung des Labmagens beim rind. Zentralblatt für Veterinärmedizin Reihe A, Berlin, v. 8, n. 9, p. 934-975, 1961.

Gegenwärtiger stand der diagnostik, therapie und prophylaxe der dislocatio abomasi sinistra des rindes. Deutsche Tierärztliche Wochenschrift, Hannover, v. 74, n. 24, p. 625-633, 1967.

DIRKSEN, G. Krankheiten der verdauungsorgane und der bauchwand. In: DIRKSEN, G.; GRÜNDER, H.D.; STÖBER, M. (Ed.). Innere medizin und chirurgie des rindes. 5. Aufl., Stuttgart: Blackwell WissenchaftsVerlag, 2006. p. 473-514.

GEISHAUSER, T. Abomasal displacement in the bovine - a review on character, occurrence, aetiology and pathogenesis. Zentralblatt für Veterinärmedizin Reihe A, Berlin, v. 42, n. 4, p. 229-251, 1995.

GNEMMI, G. Endoscopia bovina: dislocazione abomasale sinistra: approccio endoscopico one-step con animale in stazione quadrupedale: valutazione retrospettiva. Summa, Milano, n. 1, p. 11-21, 2006.

GRYMER, J.; STERNER, K. E. Percutaneous fixation of left displaced abomasum, using a bar suture. Journal of the American Veterinary Medical Association, Schaumburg, v. 180, n. 12, p. 1458-1461, 1982.

HULL, B. L. Close suturing technique for correction of left abomasal displacement. Iowa State University Veterinarian, Ames, v. 34, n. 3, p. 142-144, 1972.

ITOH, M.; SASAKI, N.; KAWAMOTO, S.; YAMADA, H.; INOKUMA, H. A mechanism of excessive accumulation of abomasal gas in vagomized cattle determined using fluoroscopy. The Journal of Veterinary Medical Science, Tokyo, v. 73, n. 5, p. 567-571, 2011.

JANOWITZ, H. Laparoskopische reposition und fixation des nach links verlagerten labmagen beim rind. Tierärztliche Praxis Ausgabe G Grosstiere/Nutztiere, Stuttgart, v. 26, n. 6, p. 308-313, 1998.

KELTON, D. F.; FUBINI, S. L. Pyloric obstruction after toggle-pin fixation of left displaced abomasum in a cow. Journal of the American Veterinary Medical Association, Schaumburg, v. 194, n. 5, p. 677-82, 1989.

LAGERWEIJ, E.; NUMANS, S. R. De operatieve behandelings methoden van eengedilateerde en gesdiloceerde lebmaag bij het hund. Tijdschrift Voor Diergeneeskunde, Amsterdam, v. 87, p. 328-337, 1962.

De operatieve behandeling von de lebmaagdislocatie bij het rund volgens de Utrechtse methode. Tijdschrift Voor Diergeneeskunde, Amsterdam, v. 93, p. 366-376, 1968. 
NEWMAN, K. D.; HARVEY, D.; ROY, J. P. Minimally invasive field abomasopexy techniques for correction and fixation of left displacement of the abomasum in dairy cows. The Veterinary Clinics of North America: Food Animal Practice, Philadelphia, v. 24, n. 2, p. 359382, 2008.

NIEHAUS, A. J. Surgery of the abomasum. The Veterinary Clinics of North America: Food Animal Practice, Philadelphia., v. 24, n. 2, p. 349-358, 2008.

POULSEN, J. S. D.; JONES, B. E. V. The influence of metabolic alkalosis and other factors on the abomasal emptying rates in goats and cows. Nordisk Veterinaermedicin, Kopenhagen, v. 26, n. 1, p. 22-30, 1974.

ROHRBACH, B. W.; CANNEDY, A. L.; FREEMAN, K.; SLENNING, B. D. Risk factors for abomasal displacement in dairy cows. Journal of the American Veterinary Medical Association, Schaumburg, v. 214, n. 11, p. 1660-1663, 1999.
SHAVER. R. D. Nutritional risk factors in the etiology of left displaced abomasum in dairy cows: a review. Journal of Dairy Science, Champaign, v. 80, n. 10, p. 2449-2453, 1997.

STRAITON, E.; MCINTEE, D. P. Correction of displaced abomasum. The Veterinary Record, London, v. 71, n. 41, p. 871-872, 1959.

SVENDSEN, P.; KRISTENSEN, B. Etiology and pathogenesis of abomasal displacement in cattle Nordisk Veterinaermedicin, Kopenhagen, v. 21, p. 1-60, 1970. Supplement 1.

VAN LEEUWEN, E.; MENSINK, M. G. S.; BONT, M. F. P. M. de. Laparoscopic reposition and fixation of the left displaced abomasum in dairy cattle practice - ten years of experience under field conditions in the Netherlands. Cattle Practice - British Cattle Veterinary Association, London, v. 17, n. 2, p. 123-127, 2009.

VLAMINCK, K.; VAN MEIRHAEGHE, H.; VAN DEN HENDE, C.; OYAERT, W.; MUYLLE, E. Einfluss von Endotoxinen auf die Labmagenentleerung beim Rind. Deutsche Tierärztliche Wochenschrift, Hannover, v. 92, n. 10, p. 392-395, 1985. 